\title{
A new occurrence of two-pyroxene granulites at Chicholi from Betul supracrustal belt in Central Indian Tectonic Zone (CITZ), MP, India
}

\author{
Manish Srivastava $^{1, *}$, S B Dwivedi ${ }^{1}$ and S P Singh ${ }^{2}$ \\ ${ }^{1}$ Department of Civil Engineering, Indian Institute of Technology (BHU), Varanasi 221 005, India. \\ ${ }^{2}$ Department of Geology, Institute of Earth Sciences, Bundelkhand University, Jhansi 284 128, India. \\ *Corresponding author.e-mail: manishs.rs.civ16@itbhu.ac.in
}

MS received 28 December 2018; revised 25 March 2019; accepted 2 May 2019

We report the new occurrence of two-pyroxene granulites from Chicholi, the Betul Group of the Central Indian Tectonic Zone (CITZ). The common mineral assemblage observed within different thin sections is orthopyroxene-clinopyroxene-hornblende-plagioclase-biotite-quartz. The textural relationship of these mineral phases shows the reaction: hornblende + quartz $=$ orthopyroxene + clinopyroxene + plagioclase. The estimated $P-T$ condition of metamorphism of the two-pyroxene granulites is $901 \pm 30^{\circ} \mathrm{C}$ and $8.68 \pm 1.4$ kbar.

Keywords. Pyroxene; granulite; CITZ; metamorphism; $P-T$ condition.

\section{Introduction}

Granulites are considered as an important window to the lower crust as they provide us an important constraint for understanding their probable nature and composition. They also provide clues for the important processes - tectonic and chemical evolution which are responsible for crustal accretion, crustal stabilization and continental growth (Harley 1989). They are considered as the major modern analogues for the study of geodynamic evolution and tectonic history of the Earth. The coexistence of two pyroxenes in a granulite has been studied from several geological formations in India such as Southern Granulite Belt (Tsunogae and Santosh 2006 and references therein), Eastern Ghats Granulite Belt (Dasgupta et al. 1993 and references therein), Chhotanagpur Granite Gneiss Complex (Karmakar et al. 2011; Chatterjee 2018 and references therein) and Shillong Meghalaya Gneissic Complex (Dwivedi and Theunuo 2011 and Published online: 22 July 2019 references therein). The supracrustal rocks of the Betul Group contain low-to-medium grade metamorphic rocks formed under amphibolite facies (Roy et al. 2003). It is an important factor which provides the clue that the protoliths might have been metamorphosed up to granulite facies, as Betul supracrustals are an active part of the Central Indian Tectonic Zone (CITZ) (Bhowmik and Roy 2003; Santosh et al. 2009; Naganjaneyulu and Santosh 2010; Vansutre and Hari 2010 and references therein). The CITZ has been considered in earlier studies as a trans-continental suture between the northern Bundelkhand Craton and Southern Bastar Craton (Harris 1993). The granulite belts have already been described from northern Bundelkhand Craton (Sharma 1988; Guha and Bhattacharya 1995; Dasgupta et al. 1997; Singh and Dwivedi 2009 and references therein) and from southern Bastar Craton (Narsimha Prakash et al. 1996; Bhowmik et al. 1999; Bhowmik and Dasgupta 2004; Das et al. 2008 and 
references therein). We report the occurrence of two-pyroxene granulites from the area of Chicholi of the Betul Group within CITZ. The petrography, mineral chemistry and geothermobarometry have been discussed in detail which provide imprints of granulite facies metamorphism within the given rock suite of the Betul Group.

\section{Geological setting}

The Central Indian region is characterised by the occurrence of small-sized granulite belts within the CITZ and adjoining cratons. The CITZ is a Proterozoic mobile belt whose regional trend is ENE-WSW. It is the zone of amalgamation of the two major cratonic blocks namely, Bundelkhand craton in the north and Bastar Craton in the south (Radhakrishna 1989; Naganjaneyulu and Santosh 2010; Acharyya and Roy 2011) (figure 1). The CITZ is sandwiched between the Son Narmada North Fault in the north and the Central Indian Shear (CIS) zone in the south. It incorporates at least three distinct supracrustal belts namely, Mahakoshal, Betul and Sausar which are composed of low-to-medium-grade metamorphosed supracrustal rocks set in largely undifferentiated gneisses and granitoids (Roy et al. 2003; Vansutre and Hari 2010). Within these supracrustals of CITZ, four prominent granulite belts are present namely:

- Balaghat-Bhandara Granulite Belt (BBG) of Sausar Series.

- Ramakona-Katangi Granulite Belt (RKG) of Sausar Series.

- Chhatuabhavna Granulite (CBG) of BilaspurRaigarh Belt.

- Makrohar Granulite Belt (MGB) of Mahakoshal supracrustals.

Chicholi village $\left(21^{\circ} 59^{\prime} 603^{\prime \prime} \mathrm{N} ; \quad 77^{\circ} 41^{\prime} 140^{\prime \prime} \mathrm{E}\right)$ is located in the Betul supracrustal belt, whose regional trend is ENE-WSW. The rock formations of the belt designated as the Betul Group are considered as a prominent division of CITZ (figure 1). The structural characteristics reveal that the supracrustal rocks have been deformed by three episodes. The first generation structures $\left(\mathrm{D}_{1}\right)$ are represented by isoclinal to reclined folds; the second generation folds $\left(D_{2}\right)$ are tight to isoclinal, upright to inclined which define the ENE-WSW regional tectonic trend of the belt. The $\mathrm{D}_{2}$ structures have been affected by superposed folding $\left(D_{3}\right)$ that has given rise to $\mathrm{N}-\mathrm{S}$ trending broad open folds. The $\mathrm{D}_{1}$ and $\mathrm{D}_{2}$ deformations are accompanied by greenschist to lower amphibolite facies metamorphism (Roy et al. 2003).

\section{Petrography}

The two-pyroxene granulites of the study area are dark grey to greyish black in colour and are medium to coarse-grained (figure $2 \mathrm{a}$ ). The rock exhibits granoblastic/granulitic texture with granular mosaic of orthopyroxene, clinopyroxene, hornblende and plagioclase. Biotite is also present in few thin sections which exhibit weak foliation. The twopyroxene granulites contain the following mineral assemblage: (i) orthopyroxene-clinopyroxene-hornblende-plagioclase-biotite-quartz.

Hornblende is strongly pleochroic with green, yellowish-green, bluish-green, dark green or greenish-brown pleochroic colours (figure $2 \mathrm{~b}$ and c). The pleochroic colour in hornblende varies with a change in chemical composition which is given in table 3. Hornblende is of two generations, hornblende 1 and hornblende 2 in which hornblende1 is corroded and occurs as inclusion within orthopyroxene providing evidence of breakdown of hornblende1 in the presence of quartz into two pyroxenes (figure $2 \mathrm{~b}$ ). Hornblende 2 is formed in the late stage during retrogression of pyroxenes (figure 2c). The mineral chemistry of hornblende is given in table 4 which shows variation in chemical composition.

Orthopyroxene is hypersthene which is colourless to pale green, slightly pleochroic and the grains are sub-idioblastic to idioblastic. Hypersthene shows low birefringence in polarized light and first-order interference colour, parallel extinction under crossed nicols of the petrological microscope. Orthopyroxene contains the inclusion of corroded hornblende (Hbl1) and quartz (figure 2b), which shows a prograde reaction as:

hornblende $1+$ quartz $=$ orthopyroxene

+ clinopyroxene + plagioclase $+\mathrm{H}_{2} \mathrm{O}$.

At some places, orthopyroxene is also partially encircled by hornblende2 (figure 2c), which shows a retrograde reaction as:

orthopyroxene + clinopyroxene + plagioclase

$+\mathrm{H}_{2} \mathrm{O}=$ hornblende $2+$ quartz. 


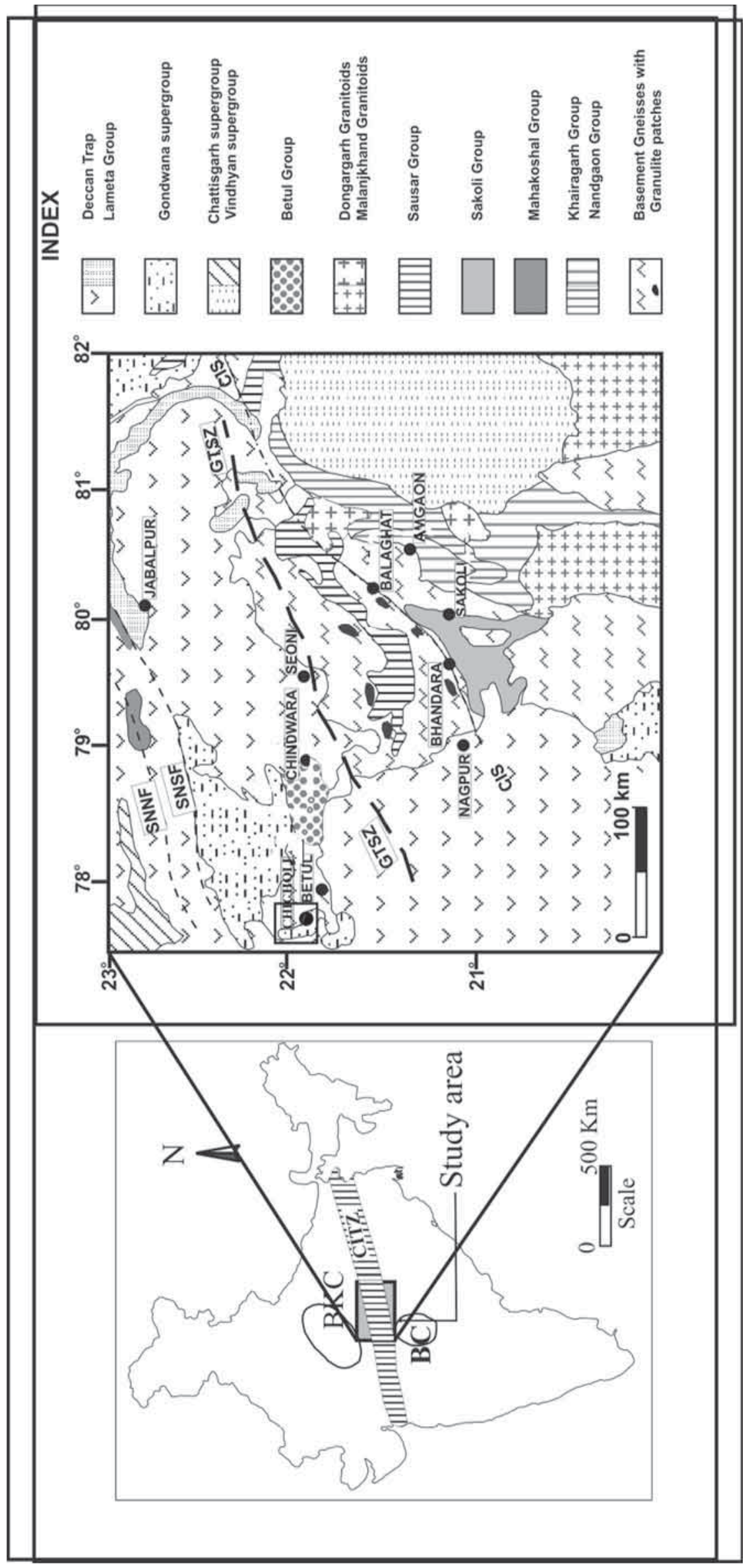

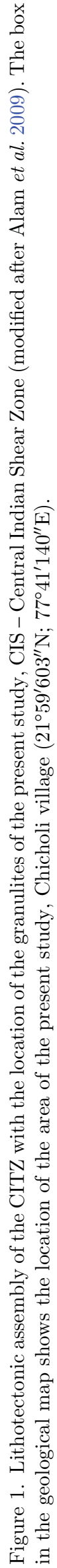



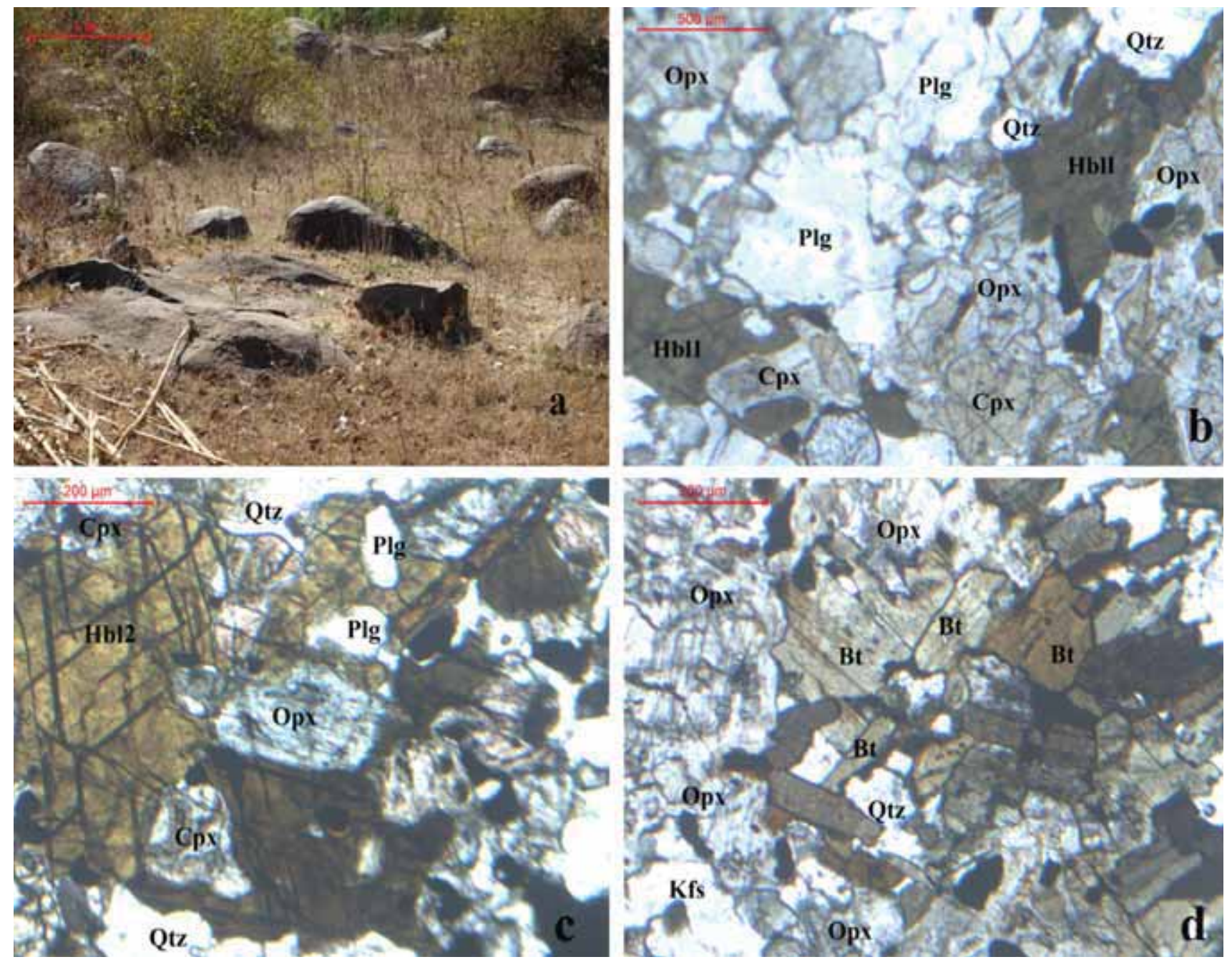

Figure 2. (a) Photograph of the two-pyroxene granulites in field which occur in the form of patches. (b) Photomicrograph of coexisting mineral phases in orthopyroxene coexisting with clinopyroxene and plagioclase contain inclusions of corroded hornblende and quartz under plane-polarised light. (c) Photomicrograph shows the inclusions of orthopyroxene, clinopyroxene and plagioclase in hornblende coexisting with quartz (plane-polarised light). (d) Photomicrograph of coexisting mineral phases shows inclusions of biotite and quartz in orthopyroxene under plane-polarised light. Where, Opx = orthopyroxene; $\mathrm{Cpx}=$ clinopyroxene, $\mathrm{Hbl}=$ hornblende, Plag = plagioclase, Bt = biotite, Kfs = alkali-feldspar and Qz = quartz $($ Whitney and Evans 2010).

Orthopyroxene also rims flakes of biotite along with quartz inclusions (figure 2d), which indicates a prograde reaction as:

Biotite + quartz $=$ orthopyroxene + alkali feldspar

$$
+ \text { vapour. }
$$

Clinopyroxene is diopside. It is colourless to pale yellow, slightly pleochroic and shows inclined extinction. Reaction (I) can also be evidenced by the occurrence of inclusions of hornblende and plagioclase in clinopyroxene (figure $2 \mathrm{~b}$ ).

Plagioclase occurs as coarse aggregates, lathshaped grains and it is characterized by polysynthetic/lamellar twinning.
Biotite is also a dominant mineral phase and it occurs as medium-grained, subidioblastic flakes. It shows strong pleochroism from colourless to light brown to dark brown to light yellow.

\section{Mineral chemistry}

Different mineral phases and assemblages were identified by detailed petrographic studies (table 1). The coexisting mineral phases have been analysed by using an electron probe micro analyser (EPMA). The analytical work was performed by using an EPMA CAMECA SXFive instrument at DST-SERB National Facility, Department of 
Table 1. Representative approximate modal composition (in percentage) of the two-pyroxene granulites observed under a petrological microscope through Leica Qwin software.

\begin{tabular}{|c|c|c|c|c|c|c|c|c|}
\hline \multirow{2}{*}{$\begin{array}{l}\text { Serial } \\
\text { no. }\end{array}$} & \multirow{2}{*}{$\begin{array}{c}\text { Sample } \\
\text { no. }\end{array}$} & \multicolumn{7}{|c|}{ Minerals } \\
\hline & & Opx & Cpx & $\mathrm{Hbl}$ & $\mathrm{Plg}$ & $\mathrm{Bt}$ & Qtz & $\mathrm{Kfs}$ \\
\hline 1 & CH-01 & 25 & 20 & 10 & 20 & 10 & 10 & 5 \\
\hline 2 & CH-02 & 25 & 20 & 15 & 25 & 5 & 5 & 5 \\
\hline 3 & $\mathrm{CH}-03$ & 20 & 20 & 10 & 20 & 15 & 5 & 5 \\
\hline 4 & CH-04 & 30 & 25 & 15 & 20 & 5 & 5 & 0 \\
\hline 5 & CH-05 & 25 & 30 & 25 & 15 & 0 & 5 & 0 \\
\hline 6 & CH-06 & 20 & 30 & 15 & 25 & 0 & 10 & 0 \\
\hline 7 & $\mathrm{CH}-07$ & 15 & 35 & 15 & 20 & 10 & 5 & 0 \\
\hline 8 & CH-08 & 30 & 30 & 10 & 15 & 10 & 5 & 0 \\
\hline 9 & CH-09 & 25 & 25 & 15 & 20 & 10 & 5 & 0 \\
\hline 10 & CH-10 & 30 & 20 & 10 & 10 & 15 & 10 & 5 \\
\hline 11 & CH-11 & 25 & 30 & 15 & 20 & 5 & 5 & 0 \\
\hline 12 & CH-12 & 35 & 25 & 10 & 25 & 0 & 5 & 0 \\
\hline 13 & CH-13 & 25 & 35 & 15 & 15 & 10 & 0 & 0 \\
\hline 14 & CH-14 & 30 & 30 & 20 & 10 & 5 & 0 & 0 \\
\hline 15 & CH-15 & 25 & 20 & 15 & 25 & 10 & 5 & 0 \\
\hline 16 & CH-16 & 30 & 25 & 20 & 15 & 5 & 5 & 0 \\
\hline 17 & CH-17 & 25 & 25 & 10 & 25 & 15 & 0 & 0 \\
\hline 18 & CH-18 & 20 & 30 & 20 & 10 & 10 & 5 & 5 \\
\hline 19 & CH-19 & 30 & 25 & 15 & 25 & 0 & 5 & 0 \\
\hline
\end{tabular}

Table 2. EPMA data and structural formula of orthopyroxene from two-pyroxene granulites on six oxygen basis.

\begin{tabular}{|c|c|c|c|c|c|c|c|c|}
\hline \multirow{2}{*}{$\begin{array}{l}\text { Sample no. } \\
\text { Oxides } \\
\end{array}$} & \multicolumn{2}{|c|}{ CH-03 } & \multicolumn{2}{|c|}{ CH-04 } & \multicolumn{2}{|c|}{ CH-06 } & \multicolumn{2}{|c|}{ CH-12 } \\
\hline & Core $1 / 1$ & $\operatorname{Rim} 1 / 1$ & Core $2 / 1$ & $\operatorname{Rim} 2 / 1$ & Core $3 / 1$ & $\operatorname{Rim} 3 / 1$ & Core 4/1 & $\operatorname{Rim} 4 / 1$ \\
\hline $\mathrm{SiO}_{2}$ & 50.02 & 50.35 & 50.23 & 50.00 & 49.90 & 50.14 & 50.33 & 50.50 \\
\hline $\mathrm{TiO}_{2}$ & 0.06 & 0.07 & 0.09 & 0.09 & 0.09 & 0.08 & 0.13 & 0.11 \\
\hline $\mathrm{Al}_{2} \mathrm{O}_{3}$ & 1.08 & 1.26 & 1.16 & 1.06 & 1.12 & 1.02 & 1.24 & 1.13 \\
\hline $\mathrm{Cr}_{2} \mathrm{O}_{3}$ & 0.01 & 0.00 & 0.02 & 0.00 & 0.02 & 0.01 & 0.04 & 0.04 \\
\hline $\mathrm{FeO}$ & 31.08 & 31.58 & 30.45 & 30.81 & 31.22 & 31.10 & 29.82 & 30.13 \\
\hline $\mathrm{MnO}$ & 0.71 & 0.96 & 0.55 & 0.56 & 0.94 & 0.94 & 0.61 & 0.65 \\
\hline $\mathrm{MgO}$ & 15.12 & 15.41 & 16.04 & 15.59 & 15.51 & 15.67 & 16.72 & 16.29 \\
\hline $\mathrm{CaO}$ & 0.76 & 0.72 & 0.70 & 0.68 & 0.90 & 0.71 & 0.82 & 1.17 \\
\hline $\mathrm{Na}_{2} \mathrm{O}$ & 0.08 & 0.07 & 0.09 & 0.17 & 0.17 & 0.12 & 0.00 & 0.01 \\
\hline $\mathrm{K}_{2} \mathrm{O}$ & 0.00 & 0.00 & 0.00 & 0.04 & 0.09 & 0.02 & 0.00 & 0.00 \\
\hline Total & 99.19 & 100.63 & 99.45 & 99.14 & 100.18 & 100.08 & 99.95 & 100.37 \\
\hline$X_{\mathrm{Mg}}$ & 0.46 & 0.46 & 0.48 & 0.47 & 0.46 & 0.47 & 0.49 & 0.49 \\
\hline $\mathrm{Si}$ & 1.97 & 1.96 & 1.96 & 1.96 & 1.95 & 1.96 & 1.95 & 1.96 \\
\hline $\mathrm{Ti}$ & 0.00 & 0.00 & 0.00 & 0.00 & 0.00 & 0.00 & 0.00 & 0.00 \\
\hline $\mathrm{Al}$ & 0.05 & 0.05 & 0.05 & 0.04 & 0.05 & 0.04 & 0.05 & 0.05 \\
\hline $\mathrm{Cr}$ & 0.00 & 0.00 & 0.00 & 0.00 & 0.00 & 0.00 & 0.00 & 0.00 \\
\hline $\mathrm{Fe}^{2+}$ & 1.02 & 1.02 & 0.99 & 1.01 & 1.02 & 1.01 & 0.96 & 0.97 \\
\hline Mn & 0.02 & 0.03 & 0.01 & 0.01 & 0.03 & 0.03 & 0.02 & 0.02 \\
\hline $\mathrm{Mg}$ & 0.88 & 0.89 & 0.93 & 0.91 & 0.90 & 0.91 & 0.96 & 0.94 \\
\hline $\mathrm{Ca}$ & 0.03 & 0.03 & 0.02 & 0.02 & 0.03 & 0.03 & 0.03 & 0.04 \\
\hline $\mathrm{Na}$ & 0.00 & 0.00 & 0.00 & 0.01 & 0.01 & 0.00 & 0.00 & 0.00 \\
\hline $\mathrm{K}$ & 0.00 & 0.00 & 0.00 & 0.00 & 0.00 & 0.00 & 0.00 & 0.00 \\
\hline Total & 4.00 & 4.01 & 4.00 & 4.01 & 4.02 & 4.01 & 4.01 & 4.00 \\
\hline
\end{tabular}

$X_{\mathrm{Mg}}=\mathrm{Mg} /(\mathrm{Mg}+\mathrm{Fe})$. 
Table 3. EPMA data and structural formula of clinopyroxene from two-pyroxene granulites on six oxygen basis.

\begin{tabular}{|c|c|c|c|c|c|c|c|c|}
\hline \multirow{2}{*}{$\begin{array}{l}\text { Sample no. } \\
\text { Oxides }\end{array}$} & \multicolumn{2}{|c|}{ CH-03 } & \multicolumn{2}{|c|}{ CH-04 } & \multicolumn{2}{|c|}{$\mathrm{CH}-06$} & \multicolumn{2}{|c|}{ CH-12 } \\
\hline & Core $1 / 1$ & $\operatorname{Rim} 1 / 1$ & Core $2 / 1$ & $\operatorname{Rim} 2 / 1$ & Core $3 / 1$ & $\operatorname{Rim} 3 / 1$ & Core $4 / 1$ & $\operatorname{Rim} 4 / 1$ \\
\hline $\mathrm{SiO}_{2}$ & 50.47 & 50.23 & 50.57 & 49.94 & 50.01 & 50.32 & 49.85 & 49.77 \\
\hline $\mathrm{TiO}_{2}$ & 0.27 & 0.22 & 0.23 & 0.30 & 0.25 & 0.26 & 0.28 & 0.26 \\
\hline $\mathrm{Al}_{2} \mathrm{O}_{3}$ & 2.12 & 2.13 & 2.21 & 2.53 & 2.52 & 2.50 & 2.23 & 1.85 \\
\hline $\mathrm{Cr}_{2} \mathrm{O}_{3}$ & 0.00 & 0.02 & 0.00 & 0.00 & 0.00 & 0.03 & 0.04 & 0.06 \\
\hline $\mathrm{FeO}$ & 12.88 & 12.64 & 14.09 & 14.55 & 14.05 & 13.91 & 12.31 & 13.66 \\
\hline $\mathrm{MnO}$ & 0.27 & 0.25 & 0.34 & 0.32 & 0.43 & 0.47 & 0.29 & 0.24 \\
\hline $\mathrm{MgO}$ & 11.19 & 11.00 & 11.20 & 10.75 & 11.01 & 10.76 & 11.00 & 11.17 \\
\hline $\mathrm{CaO}$ & 21.40 & 21.52 & 20.78 & 19.66 & 20.29 & 21.02 & 21.86 & 21.21 \\
\hline $\mathrm{Na}_{2} \mathrm{O}$ & 0.39 & 0.65 & 0.41 & 0.52 & 0.50 & 0.43 & 0.48 & 0.44 \\
\hline $\mathrm{K}_{2} \mathrm{O}$ & 0.00 & 0.04 & 0.00 & 0.04 & 0.00 & 0.00 & 0.03 & 0.00 \\
\hline Total & 99.14 & 99.15 & 100.04 & 98.85 & 99.40 & 100.00 & 98.69 & 98.89 \\
\hline$X_{\mathrm{Mg}}$ & 0.60 & 0.60 & 0.58 & 0.56 & 0.58 & 0.57 & 0.61 & 0.59 \\
\hline $\mathrm{Si}$ & 1.93 & 1.93 & 1.93 & 1.93 & 1.92 & 1.92 & 1.92 & 1.92 \\
\hline $\mathrm{Ti}$ & 0.00 & 0.00 & 0.00 & 0.00 & 0.00 & 0.00 & 0.00 & 0.00 \\
\hline $\mathrm{Al}$ & 0.09 & 0.09 & 0.10 & 0.11 & 0.11 & 0.11 & 0.10 & 0.08 \\
\hline $\mathrm{Cr}$ & 0.00 & 0.00 & 0.00 & 0.00 & 0.00 & 0.00 & 0.00 & 0.00 \\
\hline $\mathrm{Fe}^{2+}$ & 0.41 & 0.40 & 0.45 & 0.47 & 0.45 & 0.44 & 0.39 & 0.44 \\
\hline $\mathrm{Mn}$ & 0.00 & 0.00 & 0.01 & 0.01 & 0.01 & 0.01 & 0.00 & 0.00 \\
\hline $\mathrm{Mg}$ & 0.64 & 0.63 & 0.63 & 0.62 & 0.63 & 0.61 & 0.63 & 0.64 \\
\hline $\mathrm{Ca}$ & 0.88 & 0.88 & 0.85 & 0.81 & 0.83 & 0.86 & 0.90 & 0.88 \\
\hline $\mathrm{Na}$ & 0.02 & 0.04 & 0.03 & 0.03 & 0.03 & 0.03 & 0.03 & 0.03 \\
\hline K & 0.00 & 0.00 & 0.00 & 0.00 & 0.00 & 0.00 & 0.00 & 0.00 \\
\hline Total & 4.01 & 4.03 & 4.02 & 4.01 & 4.02 & 4.02 & 4.02 & 4.03 \\
\hline
\end{tabular}

Geology (Center of Advanced Study), Institute of Science, Banaras Hindu University. A total of $20-n m$ thick carbon coating was polished on thin sections for electron probe micro analyses with the help of LEICA-EM ACE200. EPMA was operated at a voltage of $15 \mathrm{kV}$ and a current of $10 \mathrm{nA}$ with the help of SXFive software. The source used for the generation of electron beam was $\mathrm{LaB}_{6}$. The internal standard used to verify positions of crystals (SP1-TAP, SP2-LiF, SP3-LPET, SP4-LTAP and SP5-PET) was andradite, which is a natural silicate mineral. The verified position was with respect to the corresponding wavelength dispersive spectrometers (SP\#) in a CAMECA SX-Five instrument. The following X-ray lines were used in the analyses: F-K $\alpha, \mathrm{Na}-\mathrm{K} \alpha, \mathrm{Mg}-\mathrm{K} \alpha, \mathrm{Al}-\mathrm{K} \alpha, \mathrm{Si}-\mathrm{K} \alpha$, $\mathrm{P}-\mathrm{K} \alpha, \mathrm{Cl}-\mathrm{K} \alpha, \mathrm{K}-\mathrm{K} \alpha$, Ca-K $\alpha$, Ti-K $\alpha, \mathrm{Cr}-\mathrm{K} \alpha, \mathrm{Mn}-\mathrm{K} \alpha$, $\mathrm{Fe}-\mathrm{K} \alpha$ and $\mathrm{Ni}-\mathrm{K} \alpha$. The natural mineral standards used during analysis are: fluorite, halite, periclase, corundum, wollastonite, apatite, orthoclase, rutile, chromite, rhodonite, hematite and pure Ni metal standard supplied by CAMECA-AMETEK, which were used for routine calibration and quantification.
Routine calibration, acquisition, quantification and data processing were carried out by using SxSAB version 6.1 and SX-result software of CAMECA (Sharma et al. 2018). EPMA data of the coexisting mineral phases with their calculated structural formula are given in tables 2-6.

The EPMA data of pyroxene were plotted in a triangular end-member $\mathrm{CaSiO}_{3}-\mathrm{MgSiO}_{3}-\mathrm{Fe}^{2+} \mathrm{SiO}_{3}$ diagram (figure 3). The orthopyroxene plots at $\mathrm{En}_{46-49}$ near the hypersthene, which is the solid solution between $\mathrm{Mg}$ and $\mathrm{Fe}$ end-members of orthopyroxene $\left(X_{\mathrm{Mg}}=0.46-0.49\right)$ and the $\mathrm{Al}$ content of the orthopyroxene varies between 0.04 and 0.05 per formula unit (pfu, on the basis of six oxygens). The clinopyroxene plots in the field of salite near the diopside end of the diagram $\left(X_{\mathrm{Mg}}=0.59-0.61\right)$ and the $\mathrm{Al}$ content ranges from 0.08 to $0.11 \mathrm{pfu}$. The Ca content of clinopyroxene varies between 0.81 and 0.90 pfu.

The hornblende in two-pyroxene granulites is of two generation which is clearly indicated in mineral chemistry obtained through EPMA. The Mg content of Hbl1 ranges from 2.00 to 2.03 pfu in its 
core portion and it is a part of the prograde metamorphic reaction. The $\mathrm{Mg}$ content of $\mathrm{Hbl} 2$ ranges from 1.92 to $1.94 \mathrm{pfu}$ in its core portion and it is retrograded in nature. The overall $\mathrm{Al}$ content of hornblende varies from 1.85 to 2.05 pfu from the structural formula calculated at 23 oxygen basis. The $X_{\mathrm{Mg}}$ of hornblende varies from 0.42 to 0.46 . The Ti content of hornblende varies between 0.24 and 0.31 pfu and wt\% of $\mathrm{TiO}_{2}$ varies from 2.12 to 2.75. Hornblende is calcic in nature, which is evident from high calcium content ranging from 1.87 to $1.98 \mathrm{pfu}$. The EPMA data plot for amphibole classification (Leake et al. 1997) is shown in figure 4.

The $X_{\mathrm{Mg}}$ content of biotite ranges from $0.43-0.45$ which shows predominance of iron over magnesium. The $\mathrm{TiO}_{2}$ content ranges from $3.56 \%$ to $3.96 \%$. The $\mathrm{Al}_{2} \mathrm{O}_{3}$ content ranges from $13.67 \%$ to $14.81 \%$ while $\mathrm{Al}^{\mathrm{IV}}$ content lies in between 2.42 and $2.52 \mathrm{pfu}$ and $\mathrm{Al}^{\mathrm{VI}}$ ranges from 0.11 to 0.20 pfu.

The EPMA data and the calculated structural formula indicate the presence of labradorite type of plagioclase which is rich in calcium than potassium. The An-content of plagioclase ranges from $\mathrm{An}_{50}$ to $\mathrm{An}_{58}$ which was calculated using the relation $\mathrm{Ca} /(\mathrm{Ca}+\mathrm{Na}+\mathrm{K})$.

\section{Geothermobarometry}

The metamorphic condition was estimated by quantification of $P-T$ condition for the granulites by orthopyroxene-clinopyroxene conventional exchange geothermobarometers (table 6), and also from an internally consistent dataset with the help of Thermocalc v. 3.21 (Holland and Powell 1998) at $9 \mathrm{kbar}$ (table 7). The estimates of temperature of the coexisting orthopyroxene-clinopyroxene from the granulites range between 845 and $962^{\circ} \mathrm{C}$ for the core and $779-870^{\circ} \mathrm{C}$ for the rim. The average temperature of the core is $889 \pm 35^{\circ} \mathrm{C}$ and the average temperature of the rim is $800 \pm 38^{\circ} \mathrm{C}$. The average $P-T$ condition of metamorphism

Table 4. EPMA data and structural formula of hornblende from two-pyroxene granulites on 23 oxygen basis.

\begin{tabular}{|c|c|c|c|c|c|c|c|c|}
\hline \multirow{2}{*}{$\begin{array}{l}\text { Sample no. } \\
\text { Oxides }\end{array}$} & \multicolumn{2}{|c|}{ CH-04 (Hbl1) } & \multicolumn{2}{|c|}{ CH-06 (Hbl1) } & \multicolumn{2}{|c|}{ CH-12 (Hbl2) } & \multicolumn{2}{|c|}{ CH-03 (Hbl2) } \\
\hline & Core 2/1 & $\operatorname{Rim} 2 / 1$ & Core 3/1 & $\operatorname{Rim} 3 / 1$ & Core 4/1 & $\operatorname{Rim} 4 / 1$ & Core 1/1 & $\operatorname{Rim} 1 / 1$ \\
\hline $\mathrm{SiO}_{2}$ & 40.81 & 41.15 & 40.64 & 40.39 & 39.76 & 40.42 & 40.24 & 41.31 \\
\hline $\mathrm{TiO}_{2}$ & 2.37 & 2.75 & 2.12 & 2.55 & 2.65 & 2.37 & 2.20 & 2.30 \\
\hline $\mathrm{Al}_{2} \mathrm{O}_{3}$ & 10.99 & 10.22 & 11.25 & 11.10 & 11.01 & 10.69 & 10.73 & 10.71 \\
\hline $\mathrm{Cr}_{2} \mathrm{O}_{3}$ & 0.00 & 0.00 & 0.00 & 0.00 & 0.00 & 0.00 & 0.00 & 0.00 \\
\hline $\mathrm{FeO}$ & 18.88 & 19.33 & 18.84 & 19.12 & 19.20 & 19.28 & 19.45 & 18.32 \\
\hline $\mathrm{MnO}$ & 0.08 & 0.19 & 0.16 & 0.29 & 0.25 & 0.21 & 0.27 & 0.28 \\
\hline $\mathrm{MgO}$ & 8.67 & 9.01 & 8.81 & 8.34 & 8.31 & 8.19 & 8.23 & 9.05 \\
\hline $\mathrm{CaO}$ & 11.37 & 11.77 & 11.68 & 11.42 & 11.48 & 11.73 & 11.78 & 11.31 \\
\hline $\mathrm{Na}_{2} \mathrm{O}$ & 1.30 & 1.22 & 1.24 & 1.17 & 1.43 & 1.22 & 1.18 & 1.17 \\
\hline $\mathrm{K}_{2} \mathrm{O}$ & 1.77 & 1.70 & 1.83 & 1.84 & 1.91 & 1.77 & 1.80 & 1.77 \\
\hline $\mathrm{ZrO}_{2}$ & 0.00 & 0.00 & 0.00 & 0.00 & 0.00 & 0.00 & 0.00 & 0.00 \\
\hline Total & 96.91 & 97.97 & 97.51 & 96.97 & 96.81 & 96.55 & 96.57 & 96.86 \\
\hline$X_{\mathrm{Mg}}$ & 0.44 & 0.45 & 0.45 & 0.43 & 0.43 & 0.42 & 0.43 & 0.46 \\
\hline $\mathrm{Si}$ & 6.34 & 6.34 & 6.30 & 6.29 & 6.23 & 6.33 & 6.32 & 6.39 \\
\hline $\mathrm{Ti}$ & 0.27 & 0.31 & 0.24 & 0.29 & 0.31 & 0.27 & 0.25 & 0.26 \\
\hline $\mathrm{Al}$ & 2.01 & 1.85 & 2.05 & 2.04 & 2.03 & 1.97 & 1.98 & 1.95 \\
\hline $\mathrm{Cr}$ & 0.00 & 0.00 & 0.00 & 0.00 & 0.00 & 0.00 & 0.00 & 0.00 \\
\hline $\mathrm{Fe}^{2+}$ & 2.45 & 2.49 & 2.44 & 2.49 & 2.51 & 2.52 & 2.55 & 2.37 \\
\hline Mn & 0.01 & 0.02 & 0.02 & 0.03 & 0.03 & 0.02 & 0.03 & 0.03 \\
\hline $\mathrm{Mg}$ & 2.00 & 2.07 & 2.03 & 1.94 & 1.94 & 1.91 & 1.92 & 2.09 \\
\hline $\mathrm{Ca}$ & 1.88 & 1.94 & 1.94 & 1.90 & 1.93 & 1.97 & 1.98 & 1.87 \\
\hline $\mathrm{Na}$ & 0.39 & 0.36 & 0.37 & 0.35 & 0.43 & 0.37 & 0.36 & 0.35 \\
\hline $\mathrm{K}$ & 0.35 & 0.33 & 0.36 & 0.36 & 0.38 & 0.35 & 0.00 & 0.34 \\
\hline $\mathrm{Zr}$ & 0.00 & 0.00 & 0.00 & 0.00 & 0.00 & 0.00 & 0.00 & 0.00 \\
\hline Total & 15.74 & 15.75 & 15.78 & 15.74 & 15.83 & 15.75 & 15.78 & 15.70 \\
\hline
\end{tabular}

$X_{\mathrm{Mg}}=\mathrm{Mg} /(\mathrm{Mg}+\mathrm{Fe})$. 
Table 5. EPMA data and structural formula of biotite from two-pyroxene granulites on 22 oxygen basis.

\begin{tabular}{|c|c|c|c|c|c|c|}
\hline \multirow{2}{*}{$\begin{array}{l}\text { Sample no. } \\
\text { Oxides }\end{array}$} & \multicolumn{2}{|c|}{$\mathrm{CH}-03$} & \multicolumn{2}{|c|}{$\mathrm{CH}-04$} & \multicolumn{2}{|c|}{$\mathrm{CH}-12$} \\
\hline & Core $1 / 1$ & $\operatorname{Rim} 1 / 1$ & Core $2 / 1$ & $\operatorname{Rim} 2 / 1$ & Core $3 / 1$ & $\operatorname{Rim} 3 / 1$ \\
\hline $\mathrm{SiO}_{2}$ & 35.04 & 34.99 & 35.11 & 35.02 & 35.12 & 34.96 \\
\hline $\mathrm{TiO}_{2}$ & 3.56 & 3.76 & 3.79 & 3.96 & 3.72 & 3.61 \\
\hline $\mathrm{Al}_{2} \mathrm{O}_{3}$ & 13.89 & 14.05 & 13.88 & 13.67 & 13.80 & 14.81 \\
\hline $\mathrm{Cr}_{2} \mathrm{O}_{3}$ & 0.04 & 0.03 & 0.02 & 0.01 & 0.01 & 0.06 \\
\hline $\mathrm{FeO}$ & 21.25 & 22.09 & 21.22 & 21.56 & 21.22 & 21.96 \\
\hline $\mathrm{MnO}$ & 0.07 & 0.07 & 0.06 & 0.13 & 0.00 & 0.12 \\
\hline $\mathrm{MgO}$ & 10.05 & 9.78 & 9.98 & 9.59 & 9.80 & 9.88 \\
\hline $\mathrm{CaO}$ & 0.02 & 0.00 & 0.00 & 0.04 & 0.04 & 0.01 \\
\hline $\mathrm{BaO}$ & 0.00 & 0.00 & 0.00 & 0.00 & 0.00 & 0.00 \\
\hline $\mathrm{Na}_{2} \mathrm{O}$ & 0.23 & 0.21 & 0.19 & 0.28 & 0.31 & 0.13 \\
\hline $\mathrm{K}_{2} \mathrm{O}$ & 8.30 & 8.08 & 8.09 & 8.30 & 8.30 & 8.26 \\
\hline $\mathrm{Cl}$ & 0.26 & 0.31 & 0.31 & 0.38 & 0.39 & 0.26 \\
\hline $\mathrm{F}$ & 0.37 & 0.04 & 0.18 & 0.37 & 0.34 & 0.36 \\
\hline Total & 93.37 & 93.59 & 92.91 & 93.36 & 93.31 & 94.75 \\
\hline$X_{\mathrm{Mg}}$ & 0.45 & 0.44 & 0.45 & 0.43 & 0.45 & 0.44 \\
\hline $\mathrm{Si}$ & 5.56 & 5.52 & 5.56 & 5.55 & 5.57 & 5.47 \\
\hline $\mathrm{Al}^{\mathrm{IV}}$ & 2.43 & 2.47 & 2.43 & 2.44 & 2.42 & 2.52 \\
\hline $\mathrm{Cr}$ & 0.00 & 0.00 & 0.00 & 0.00 & 0.00 & 0.00 \\
\hline $\mathrm{Al}^{\mathrm{VI}}$ & 0.15 & 0.14 & 0.15 & 0.11 & 0.15 & 0.20 \\
\hline $\mathrm{Ti}$ & 0.42 & 0.44 & 0.45 & 0.47 & 0.44 & 0.42 \\
\hline $\mathrm{Fe}^{2+}$ & 2.81 & 2.91 & 2.81 & 2.86 & 2.81 & 2.87 \\
\hline $\mathrm{Mn}$ & 0.01 & 0.01 & 0.00 & 0.01 & 0.00 & 0.01 \\
\hline $\mathrm{Ba}$ & 0.00 & 0.00 & 0.00 & 0.00 & 0.00 & 0.00 \\
\hline $\mathrm{Mg}$ & 2.37 & 2.30 & 2.35 & 2.27 & 2.31 & 2.30 \\
\hline $\mathrm{Ca}$ & 0.00 & 0.00 & 0.00 & 0.00 & 0.00 & 0.00 \\
\hline $\mathrm{Na}$ & 0.07 & 0.06 & 0.05 & 0.08 & 0.09 & 0.04 \\
\hline K & 1.68 & 1.62 & 1.63 & 1.68 & 1.68 & 1.65 \\
\hline $\mathrm{Cl}$ & 0.07 & 0.08 & 0.08 & 0.10 & 0.10 & 0.07 \\
\hline $\mathrm{F}$ & 0.18 & 0.02 & 0.09 & 0.18 & 0.17 & 0.17 \\
\hline Total & 15.55 & 15.52 & 15.49 & 15.52 & 15.52 & 15.53 \\
\hline
\end{tabular}

$X_{\mathrm{Mg}}=\mathrm{Mg} /(\mathrm{Mg}+\mathrm{Fe})$.

$\left(P-T_{\text {av }}\right)$ was estimated using Thermocalc v. 3.21 with EPMA data of two-pyroxene granulites and with phases involving orthopyroxene, clinopyroxene, hornblende and plagioclase. The estimated average $P-T$ condition of granulite facies metamorphism is $901 \pm 30^{\circ} \mathrm{C} / 8.68 \pm 1.4 \mathrm{kbar}$ and the independent set of reactions involved are given in table 8 .

\section{Discussion}

The two-pyroxene granulites have been studied and identified based on petrography and mineral chemistry. The different thin sections were examined and mineral phases were identified with the help of their characteristic optical properties. The mutual relationship of different mineral phases led to the establishment of definite metamorphic reactions. Mineral chemistry was studied with the help of the EPMA analytical technique. The twopyroxene granulites of the Chicholi region are found to contain orthopyroxene-clinopyroxenehornblende-plagioclase-biotite-quartz as an essential mineral assemblage. Based on the EPMA analytical studies, it has been proved that the orthopyroxene is hypersthene $\left(\mathrm{En}_{46-49}\right)$ and the clinopyroxene is salite which is a characteristic feature of basic granulites. The anorthite content of plagioclase, $\mathrm{An}_{49}-\mathrm{An}_{51}$ suggests the presence of labradorite. The textural relationship of minerals shows the evidence of the following reactions: (i) hornblende $1+$ quartz $=$ orthopyroxene + clinopyroxene + plagioclase $+\mathrm{H}_{2} \mathrm{O}$, which is evident from the relicts of hornblende within the hyper- 
Table 6. EPMA and structural formula of plagioclase from two-pyroxene granulites on eight oxygen basis.

\begin{tabular}{|c|c|c|c|c|c|c|c|}
\hline \multirow{2}{*}{$\begin{array}{l}\text { Sample no. } \\
\text { Oxides }\end{array}$} & \multicolumn{2}{|c|}{$\mathrm{CH}-03$} & \multicolumn{2}{|c|}{ CH-04 } & \multicolumn{2}{|c|}{$\mathrm{CH}-06$} & \multirow{2}{*}{$\frac{\mathrm{CH}-12}{\mathrm{Core} 4 / 1}$} \\
\hline & Core $1 / 1$ & $\operatorname{Rim} 1 / 1$ & Core $2 / 1$ & $\operatorname{Rim} 2 / 1$ & Core $3 / 1$ & $\operatorname{Rim} 3 / 1$ & \\
\hline $\mathrm{SiO}_{2}$ & 52.81 & 54.68 & 54.59 & 54.84 & 55.00 & 55.00 & 51.10 \\
\hline $\mathrm{Al}_{2} \mathrm{O}_{3}$ & 27.28 & 27.08 & 27.82 & 27.01 & 27.65 & 27.80 & 30.43 \\
\hline $\mathrm{FeO}$ & 0.15 & 0.00 & 0.00 & 0.00 & 0.00 & 0.00 & 0.04 \\
\hline $\mathrm{CaO}$ & 11.63 & 11.06 & 10.89 & 10.82 & 10.95 & 10.48 & 12.24 \\
\hline $\mathrm{Na}_{2} \mathrm{O}$ & 5.71 & 5.53 & 5.29 & 5.71 & 5.42 & 5.58 & 4.67 \\
\hline $\mathrm{K}_{2} \mathrm{O}$ & 0.59 & 0.13 & 0.11 & 0.13 & 0.10 & 0.08 & 0.18 \\
\hline $\mathrm{BaO}$ & 0.00 & 0.00 & 0.00 & 0.00 & 0.00 & 0.00 & 0.00 \\
\hline Total & 98.73 & 98.77 & 98.84 & 98.76 & 99.22 & 99.11 & 98.99 \\
\hline$X_{\mathrm{Ca}}$ & 0.51 & 0.52 & 0.52 & 0.50 & 0.52 & 0.50 & 0.58 \\
\hline $\mathrm{Si}$ & 9.80 & 10.02 & 9.96 & 10.04 & 10.00 & 10.00 & 9.40 \\
\hline $\mathrm{Al}$ & 5.96 & 5.85 & 5.98 & 5.83 & 5.92 & 5.96 & 6.60 \\
\hline $\mathrm{Fe}^{2+}$ & 0.02 & 0.00 & 0.00 & 0.00 & 0.00 & 0.00 & 0.00 \\
\hline $\mathrm{Ca}$ & 2.31 & 2.17 & 2.13 & 2.12 & 2.13 & 2.04 & 2.41 \\
\hline $\mathrm{Na}$ & 2.05 & 1.96 & 1.87 & 2.02 & 1.91 & 1.96 & 1.66 \\
\hline K & 0.14 & 0.03 & 0.02 & 0.03 & 0.02 & 0.02 & 0.04 \\
\hline $\mathrm{Ba}$ & 0.00 & 0.00 & 0.00 & 0.00 & 0.00 & 0.00 & 0.00 \\
\hline Total & 20.30 & 20.04 & 19.98 & 20.06 & 20.00 & 20.00 & 20.14 \\
\hline
\end{tabular}

$X_{\mathrm{Ca}}=\mathrm{Ca} /(\mathrm{Ca}+\mathrm{K}+\mathrm{Na})$.

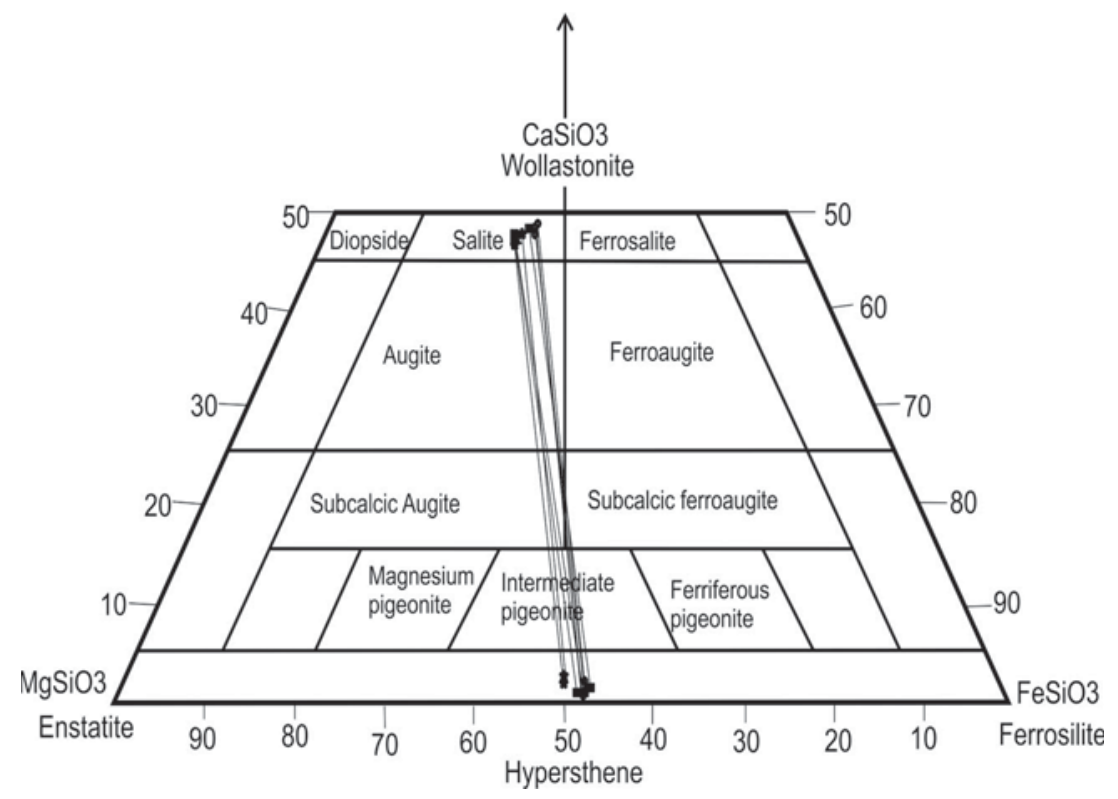

Figure 3. Representation of EPMA data of pyroxene shown in pyroxene quadrilateral (part of the triangular diagram $\mathrm{CaSiO}_{3}-\mathrm{MgSiO}_{3}-\mathrm{FeSiO}_{3}$ ). The clinopyroxene coexisting with orthopyroxene is joined by a line.

sthene (orthopyroxene) and (ii) biotite + quartz $=$ orthopyroxene $+\mathrm{K}$-feldspar $+\mathrm{H}_{2} \mathrm{O}$ which is shown by the inclusions of biotite flakes within orthopyroxene grains and both the reactions are prograde reactions. It is clear from the reactions that hornblende becomes unstable in the presence of quartz and recrystallises in orthopyroxene, clinopyroxene and plagioclase in response to the changing
$P-T$ condition. Similarly, biotite gives the stable phases of orthopyroxene and alkali feldspar by the above reaction in response to the metamorphic process. In few thin sections, textural relations where both orthopyroxene and clinopyroxene are partially rimmed by hornblende suggest the retrograde reaction: Orthopyroxene + clinopyroxene + plagioclase $+\mathrm{H}_{2} \mathrm{O}=$ hornblende $2+$ quartz. Based on the 


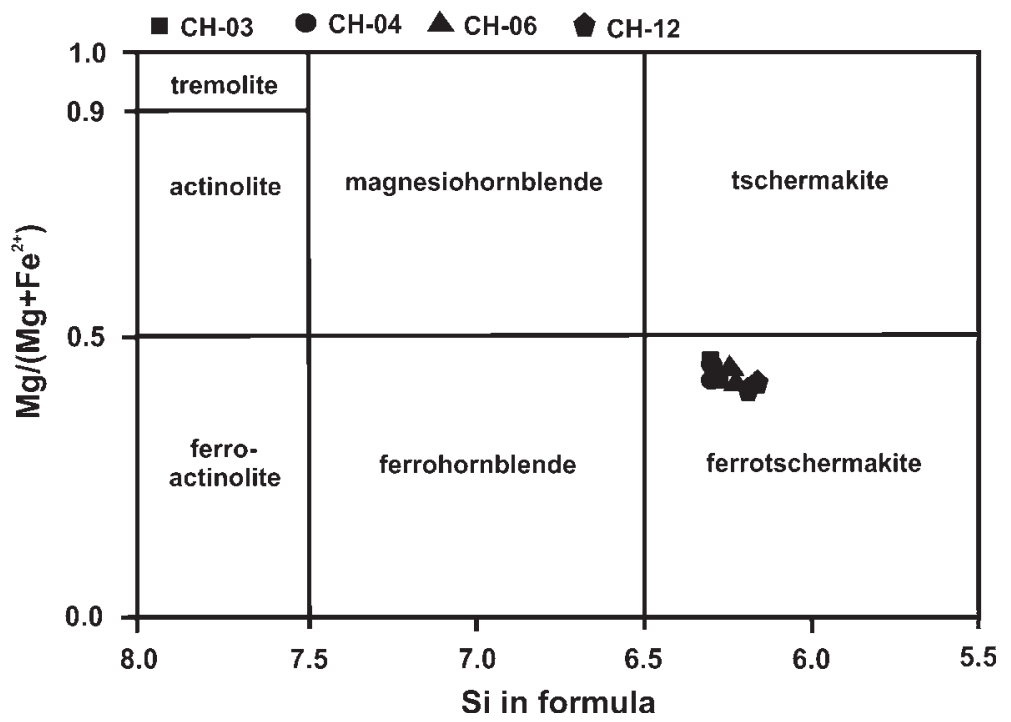

Figure 4. Representation of the EPMA data of amphibole (after Leake et al. 1997).

Table 7. Temperature estimates of two-pyroxene granulites from conventional exchange geothermometer at assumed pressure.

\begin{tabular}{|c|c|c|c|c|c|c|}
\hline \multicolumn{7}{|c|}{ Estimate of geothermometers (temp. in ${ }^{\circ} \mathrm{C}$ ) at $9 \mathrm{kbar}$} \\
\hline \multirow{2}{*}{$\begin{array}{l}\text { Models } \\
\text { Domain }\end{array}$} & \multicolumn{2}{|c|}{ Wood and Banno (1973) } & \multicolumn{2}{|c|}{ Wells (1977) } & \multicolumn{2}{|c|}{ Powell (1978) } \\
\hline & Core $\left({ }^{\circ} \mathrm{C}\right)$ & $\operatorname{Rim}\left({ }^{\circ} \mathrm{C}\right)$ & Core $\left({ }^{\circ} \mathrm{C}\right)$ & $\operatorname{Rim}\left({ }^{\circ} \mathrm{C}\right)$ & Core $\left({ }^{\circ} \mathrm{C}\right)$ & $\operatorname{Rim}\left({ }^{\circ} \mathrm{C}\right)$ \\
\hline $\mathrm{CH}-03$ & 845 & 793 & 891 & 847 & 899 & 851 \\
\hline $\mathrm{CH}-04$ & 869 & 825 & 902 & 856 & 903 & 870 \\
\hline $\mathrm{CH}-06$ & 872 & 780 & 898 & 849 & 909 & 845 \\
\hline $\mathrm{CH}-12$ & 844 & 779 & 880 & 796 & 962 & 849 \\
\hline Average & $857 \pm 25$ & $794 \pm 30$ & $892 \pm 25$ & $837 \pm 42$ & $918 \pm 40$ & $853 \pm 30$ \\
\hline
\end{tabular}

Average temperature for core $=889 \pm 35^{\circ} \mathrm{C}$.

Average temperature for $\operatorname{rim}=828 \pm 38^{\circ} \mathrm{C}$.

Table 8. Pressure and temperature estimates of two-pyroxene granulites using internally consistent dataset by Thermocalc v3.21.

\begin{tabular}{|c|c|c|c|}
\hline $\begin{array}{l}\text { Sample } \\
\text { no. }\end{array}$ & $\begin{array}{c}\text { Average pressure } \\
\text { in kbar } \\
\left(P_{\mathrm{av}}\right) \\
\end{array}$ & $\begin{array}{c}\text { Average } \\
\text { temperature } \\
\text { in }{ }^{\circ} \mathrm{C}\left(T_{\mathrm{av}}\right)\end{array}$ & $\begin{array}{l}\text { Average pressure } \\
\text { and temperature } \\
\qquad\left(P-T_{\mathrm{av}}\right)\end{array}$ \\
\hline $\mathrm{CH}-03$ & $10.55 \pm 1.2$ & $845 \pm 42$ & $894 \pm 45^{\circ} \mathrm{C} / 9.31 \pm 1.5 \mathrm{kbar}$ \\
\hline $\mathrm{CH}-04$ & $9.43 \pm 1.3$ & $963 \pm 45$ & $879 \pm 55^{\circ} \mathrm{C} / 8.44 \pm 1.6 \mathrm{kbar}$ \\
\hline $\mathrm{CH}-06$ & $8.87 \pm 1.5$ & $896 \pm 35$ & $905 \pm 40^{\circ} \mathrm{C} / 8.73 \pm 1.2 \mathrm{kbar}$ \\
\hline $\mathrm{CH}-12$ & $9.12 \pm 1.5$ & $904 \pm 50$ & $927 \pm 35^{\circ} \mathrm{C} / 8.24 \pm 1.5 \mathrm{kbar}$ \\
\hline Average & $9.49 \pm 1.5$ & $902 \pm 52$ & $901 \pm 30^{\circ} \mathrm{C} / 8.68 \pm 1.4 \mathrm{kbar}$ \\
\hline
\end{tabular}

Independent set of reactions involved in $P-T$ estimation:

1. 5 ts +10 hed $+10 q=3 \operatorname{tr}+2$ fact +10 an.

2. ts + en +2 hed $+2 \mathrm{q}=\operatorname{tr}+2 \mathrm{an}+$ fs.

3. $2 \mathrm{ts}+5 \mathrm{fs}+4 \mathrm{di}+4 \mathrm{q}=2$ fact $+4 \mathrm{an}+5 \mathrm{en}$.

4. $\operatorname{parg}+\mathrm{di}+5 \mathrm{q}=\operatorname{tr}+\mathrm{an}+\mathrm{ab}$.

5. 6 fact $+16 \mathrm{ts}+12 \mathrm{ab}+38 \mathrm{cats}=12 \mathrm{parg}+58 \mathrm{an}+15 \mathrm{fs}+10 \mathrm{H}_{2} \mathrm{O}$.

6 . parg $+2 \mathrm{fs}+$ hed $+4 \mathrm{q}=$ fact $+\mathrm{ab}+2 \mathrm{en}+$ cats.

Symbols. di: diopside, hed: hedenbergite, en: enstatite, fs: ferrosilite, tr: tremolite, fact: ferroactinolite, ts: tschermakite, parg: pargasite, an: anorthite, ab: albite, q: quartz, and $\mathrm{H}_{2} \mathrm{O}$ : water fluid. 
geothermobarometric calculations it has been derived that the two-pyroxene granulites were formed under the ultra-high temperature (UHT) conditions (at $900-1100^{\circ} \mathrm{C}$ and $7-13$ kbar) of metamorphism (Harley 1998). The average pressure of the two-pyroxene granulites of the study area is $\sim 8.75 \mathrm{kbar}$, which corresponds to about 30 $\mathrm{km}(3.5 \mathrm{~km} / \mathrm{kbar})$ depth of burial of the protoliths and the present average crustal thickness of the central Indian region is $\sim 35 \mathrm{~km}$. This indicates that the crust was doubly thickened to $\sim 65 \mathrm{~km}$ at the time of the thermal peak of metamorphism during the evolution of granulites (Ellis 1987) and suturing of the Northern Indian block and Southern Indian block along the CITZ occurred. Apart from this, lateral transportation of lower crustal rocks may have contributed to the crustal thickening in addition to under plate and intraplate magmatism, metamorphism and tectonism. These processes might also have facilitated the evolution of the granulites (Dessai et al. 2010). Further, they might have been exhumed onto the surface due to tectonic processes and have suffered denudation by the effect of geological agencies which clearly attribute to their occurrence on the surface as patches.

\section{Conclusion}

Based on the work carried out, it has been conrmed that the rock samples collected from the area of Chicholi are two-pyroxene granulites which occur within the supracrustal rocks of the Betul group. The common mineral assemblage inferred from the studies is orthopyroxene-clinopyroxenehornblende-plagioclase-biotite-quartz. Based on geothermobarometry, it is evident that the protoliths have been metamorphosed under high-grade granulite facies. The pressure-temperature condition of two-pyroxene granulites is $901 \pm 30^{\circ} \mathrm{C}$ and $8.68 \pm 1.4$ kbar.

\section{Acknowledgements}

We are thankful to the Director, Indian Institute of Technology (BHU) for providing infrastructures and funds for the completion of this work. We also extend our gratitude towards the department for providing valuable Research Support Grant needed for research purpose. We appreciate the efforts of both anonymous reviewers for their constructive comments to improve the quality of the manuscript.

\section{References}

Acharyya K and Roy A 2011 Tectonothermal history of the Central Indian Tectonic Zone and reactivation of major faults/shear zones; J. Geol. Soc. India 55 239-256.

Alam M, Naushad M, Wanjari N and Ahmad T 2009 Geochemical characterizations of mafic magmatic rocks of the Central Indian Shield: Implication for Precambrian crustal evolution; In: Geological anatomy of India and the Middle East (eds) Talat A, Francis H and Punya C, J. Virtual Explorer 32, paper 8, ISSN 1441-8142.

Bhowmik S K and Dasgupta S 2004 Tectonometamorphic evolution of boudin-type granulites in the Central Indian Tectonic Zone and in the Aravalli-Delhi mobile belt: A synthesis and future prospective; Geol. Surv. India, Spec. Publ. 84 227-246.

Bhowmik S K and Roy A 2003 Garnetiferous metabasites from the Sausar Mobile Belt: Petrology, $P-T$ path and implications for the tectonothermal evolution of the Central Indian Tectonic Zone; J. Petrol. 44 387-420.

Bhowmik S K, Pal T, Roy A and Pant N C 1999 Evidence for Pre-Grenville high-pressure granulite metamorphism from the northern margin of the Sausar mobile belt in central India; J. Geol. Soc. India 53 385-399.

Chatterjee N 2018 An assembly of the Indian Shield at c. 1.0 $\mathrm{Ga}$ and shearing at c. 876-784 Ma in Eastern India: Insights from contrasting $P-T$ paths, and burial and exhumation rates of metapelitic granulites; Precamb. Res. 317 117-136.

Das S, Bhattacharya A and Swaminathan S 2008 The thrustcontact between the Eastern Ghats Belt and the adjoining Bastar craton (Eastern India): Evidence from mafic granulites and tectonic implications; Precamb. Res. 162 70-85.

Dasgupta S, Sengupta P, Mondal A and Fukuoka M 1993 Mineral chemistry and reaction textures in metabasites from the Eastern Ghats belt, India and their implications; Mineral. Mag. 57 113-120.

Dasgupta S, Guha D, Sengupta P, Miura H and Ehl J 1997 Pressure-temperature-fluid evolutionary history of the Sandmata granulite complex, northwestern India; Precamb. Res. 83 267-290.

Dessai A G, Peinado M, Gokarn S G and Downes H 2010 Structure of the deep crust beneath the Central Indian Tectonic Zone: An integration of geophysical and xenolith data; Gondwana Res. 17 162-170.

Dwivedi S B and Theunuo K 2011 Two-pyroxene mafic granulites from Patharkhang, Shillong-Meghalaya Gneissic Complex; Curr. Sci. 100 100-105.

Ellis D J 1987 Origin and evolution of granulites in normal and thickened crust; Geology 15 167-170.

Guha D B and Bhattacharya A K 1995 Metamorphic evolution and high grade re-working of the Sandmata Complex granulites; In: Continental crust of Northwestern and Central India (eds) Sinha-Roy S and Gupta K R, Geol. Soc. India Memoir, Bangalore 31 163-198.

Harley S L 1989 The origin of granulites: A metamorphic perspective; Geol. Mag. 126 215-247. 
Harley S L 1998 On the occurrence and characterization of ultra-high temperature crustal metamorphism; In: What drives metamorphism and metamorphic reactions? (eds) Treloar P J and O'Brien P J, Geol. Soc. London 138 81-107 (special publication).

Harris L B 1993 Correlation between the Central Indian Tectonic Zone and the Albany Mobile Belt of Western Australia: Evidence for a continuous Proterozoic orogenic belt; In: Gondwana 8: Assembly, evolution and dispersal (eds) Findlay R H, Unrug R, Banks M R and Veevers J J, CRC Press, Balkema, pp. 165-180.

Holland T J B and Powell R 1998 An internally-consistent thermodynamic dataset for phases of pertrological interest; J. Metamorph. Geol. 16 309-344.

Karmakar S, Bose S, Basu Sarbadhikari A and Das K 2011 Evolution of granulite enclaves and associated gneisses from Purulia, Chhotanagpur Granite Gneiss Complex, India: Evidence for 990-940 Ma tectonothermal event(s) at the eastern India cratonic fringe zone; J. Asia. Earth Sci. 41 $69-88$.

Leake B E, Woolley A R, Arps C E S, Birch W D, Gilbert M C, Grice J D, Howthorne F C, Kato A, Kisch H J, Krivovichev V G, Linthout K, Laird J, Mandarino J A, Maresch W V, Nickel E H, Rock N M S, Schumacher J C, Smith D C, Stephenson N C N, Ungaretti L, Whittaker E J W and Youzhi G 1997 Nomenclature of amphiboles: Report of the subcommittee on amphiboles of the International Mineralogical Association, Commission on new minerals and mineral names; Can. Mineral. 35 219-246.

Naganjaneyulu K and Santosh M 2010 The Central India tectonic zone: A geophysical perspective on continental amalgamation along a mesoproterozoic suture; Gondwana Res. 18 547-564.

Narsimha Prakash N K, Janardhan A S and Mishra V P 1996 Granulites of Bhopalpatnam and Kondagaon belts, Bastarcraton, MP: Petrological and fluid inclusion studies; $J$. Southeast Asian Earth Sci. 14 221-229.
Powell R 1978 Thermodynamics of pyroxene geotherms; Phil. Trans. Roy. Soc. London A 288 457-469.

Radhakrishna B P 1989 Suspect tectonostratigraphic terrain elements in the Indian subcontinent; J. Geol. Soc. India $\mathbf{3 4}$ $1-24$.

Roy A, Prasad M H, Chore S A and Vishwakarma L L 2003 Granulite facies BIF from Betulsupracrustal belt, Central India; J. Geol. Soc. India 62 635-640.

Santosh M, Maruyama S and Sato K 2009 Anatomy of a Cambrian suture in Gondwana: Pacific-type orogeny in southern India? Gondwana Res. 16 321-341.

Sharma R S 1988 Patterns of metamorphism in the Precambrian rocks of the Aravalli mountain belt; Geol. Soc. India Memoir 7 33-75.

Sharma A, Kumar D, Sahoo S and Pandit D 2018 Chrome-diopside Megacryst-bearing Lamprophyre from the Late Cretaceous Mundwara Alkaline Complex, NW India: Petrological and geodynamic implications; J. Geol. Soc. India 91 395-399.

Singh S P and Dwivedi S B 2009 Garnet-Sillimanitecordierite-quartz bearing assemblages from Archean supracrustal rocks of Bundelkhand massif, Central India; Curr. Sci. 97 103-107.

Tsunogae T and Santosh M 2006 Spinel-sapphirine-quartz bearing composite inclusion within garnet from an ultrahigh-temperature pelitic granulite: Implications for metamorphic history and P-T path; Lithos 92 524-536.

Vansutre S and Hari K R 2010 Granulite belts of Central India with special reference to the Bhopalpatnam granulite belt: Significance in crustal evolution and implications for Columbia supercontinent; J. Asian Earth Sci. 39 794-803.

Wells P R A 1977 Pyroxene thermometry in simple and complex system; Contrib. Mineral. Petrol. 62 129-139.

Whitney D L and Evans B W 2010 Abbreviations for rock forming minerals; Am. Mineral. 95 185-187.

Wood B J and Banno S 1973 Garnet-Opx and Opx-Cpx relationship in simple and complex systems; Contrib. Mineral. Petrol. 42 109-124. 